\title{
ASSESMENT OF BATHYMETRIC MAPS VIA GIS FOR WATER IN RESERVOIR
}

Avaliação de mapas batimétricos via SIG para água em reservatório

\author{
AYHAN CEYLAN ${ }^{1}$ \\ ILKE EKIZOGLU $^{2}$ \\ ${ }^{1}$ Selcuk University, Dep. of Geomatics Engineering \\ 42031, Konya, Turkey \\ ${ }^{2}$ Sinop University, Boyabat Vocational School of Higher Edicational Sinop, Turkey \\ aceylan@selcuk.edu.tr; ilk_er28@hotmail.com
}

\begin{abstract}
In order to adopt measures for storing more water in reservoirs, lakes and ponds; to prevent water pollution, protect water sources and extend the service life of these facilities, it is important for manager (Municipalities, Directorates of the State Hydraulic Works (DSHW), Irrigation Unions etc.) to know the current topographic conditions and any changes in the storage capacities of these facilities. This study aimed to identify the updated topographic and bathymetric data required for the efficient management and usage of Altınapa reservoir, changes in surface area and volume of the facility, and to form a Reservoir Information System (RIS). Two digital elevation models, from 2009 and 1984, were used to determine changes in the storage capacity of the reservoir. The calculations indicated that, within this 25 year period, the storage capacity of the reservoir decreased by $12.7 \%$ due to sedimentation. A Dam Information System (RIS) was developed from a wide range of data sources, including topographic and bathymetric data of the reservoir and its surrounding area, data on specific features such as plant cover, water quality characteristics (Temperature, Dissolved Oxygen (DO), Secchi Disk Depth (SDD) and $\mathrm{pH}$ ), geological structure, average water level, water supplied from springs, evaporation value of the reservoir, and precipitation.
\end{abstract}

Keywords: Hydrographic Map; Bathymetric Surveying; RTK-GPS; Water Management; GIS. 


\section{RESUMO}

Para armazenar mais água nos reservatórios de lagos e lagoas; evitar a poluição da água; proteger mananciais e prolongar a vida útil das instalações necessárias para isso, é importante para o gerente (de Municípios, de diretorias de Obras Hidráulicas,cooperativas de irrigação etc) conhecer as condições topográficas atuais e quaisquer alterações na capacidade de armazenamento dessas instalações. $\mathrm{O}$ presente estudo teve como objetivo identificar e atualizar a topografia e a altimetria necessárias para a gestão eficiente e do reservatório de Altınapa (Turquia), bem como acompanhar as mudanças na área e volume da represa e ciar um Sistema de Informação do Reservatório (SIR). Dois modelos digitais de elevação, a partir de dados de 1984 e 2009, foram utilizadas para calcular as alterações na capacidade de armazenamento do reservatório. Os cálculos indicaram que, dentro deste período de 25 anos, a capacidade de armazenagem do reservatório diminuiu de $12,7 \%$, devido à sedimentação. Foi desenvolvido o Sistema de Informação do Reservatório (SIR) a partir de diversas fontes de informação, incluindo dados topográficos e batimétricos do reservatório e arredores, dados sobre características específicas, tais como cobertura vegetal, qualidade da água (temperatura, oxigênio dissolvido (OD), profundidade do disco de Secchi (DDS) e pH), a estrutura geológica , o nível médio de água, a água fornecida pelas nascentes, o valor da evaporação do reservatório, e a precipitação.

Palavras-chave: Mapa Hidrográfico; Batimetria, GPS-RTK, Gerenciamento de Recursos Hídricos; GIS.

\section{INTRODUCTION}

The main objective of water policies is to appreciate the value of present waters and water springs, use them in the most efficient way and gain maximum benefit. In order to store more water in reservoir, lakes and ponds, prevent water pollution, protect water sources and extend the service life of these facilities, it is important for manager (Municipalities, DSHW, Irrigation Unions, etc.) to know the current topographic conditions and any changes in the capacities of these facilities, data about their geological structure, plant cover and water resources etc. and environmental elements and physical and chemical characteristics of the water.

Computer assisted data analysis currently plays an important role in the protection, development and management of water resources. Geographical Information Systems (GIS) are commonly used in efficient and effective data management for hydrographic data (MILLETT and EVANS, 2009).

Studies have been carried out to determine volume changes caused by sediment deposit in various dams and lakes (BODDY and GANSKE, 2005; CEYLAN et al. 2010; CEYLAN et al., 2011; CHILDS et al., 2003; DAVID et al., 2005; EL-SERSAWY, 2005; GÜVEL, 2007; KRESS et al., 2005). Previous studies examined volume changes of dam and lake reservoirs by comparing earlier bathymetric data, which was obtained through classical measuring techniques, with 
more recent bathymetric data, obtained from updated measuring equipment (GPS receiver, Total Station and digital level) and GIS techniques. Also, work on the location and removal of two planes that crashed into the Columbia River was facilitated and accelerated by examining spatial, bathymetric and attribute data using GIS techniques (CREECH et al., 2005).

The present study identified changes in water volume of the Altınapa reservoir, as a result of sedimentation over a 25 -year period, by comparing topographic and bathymetric data from 1984 to 2009. The study also aimed to present the Reservoir Information System (RIS) for use by relevant institutions, involving data on the geological structure, plant cover, physical and chemical features of the water of Altınapa reservoir and its surrounding area, and updated topographical and bathymetric information of the reservoir.

\section{MATERIAL AND METHOD}

\subsection{Study Area}

The study area is Altınapa Reservoir, located in the Meram district of Konya province, Turkey. Altınapa Reservoir is located between $37^{\circ} 54^{\prime} 32^{\prime \prime}$ and $37^{\circ} 52^{\prime} 34^{\prime \prime}$ northern latitudes and $32^{\circ} 17^{\prime} 00^{\prime \prime}$ and $32^{\circ} 18^{\prime} 45^{\prime \prime}$ eastern longitudes. Altınapa Reservoir is $20 \mathrm{~km}$ from the western part of Konya province (Figure 1). Altınapa Reservoir is a rock-fill dam built for potable water, flood control and irrigation, which has been operational since 1967.

Figure 1- General View of Altınapa reservoir.

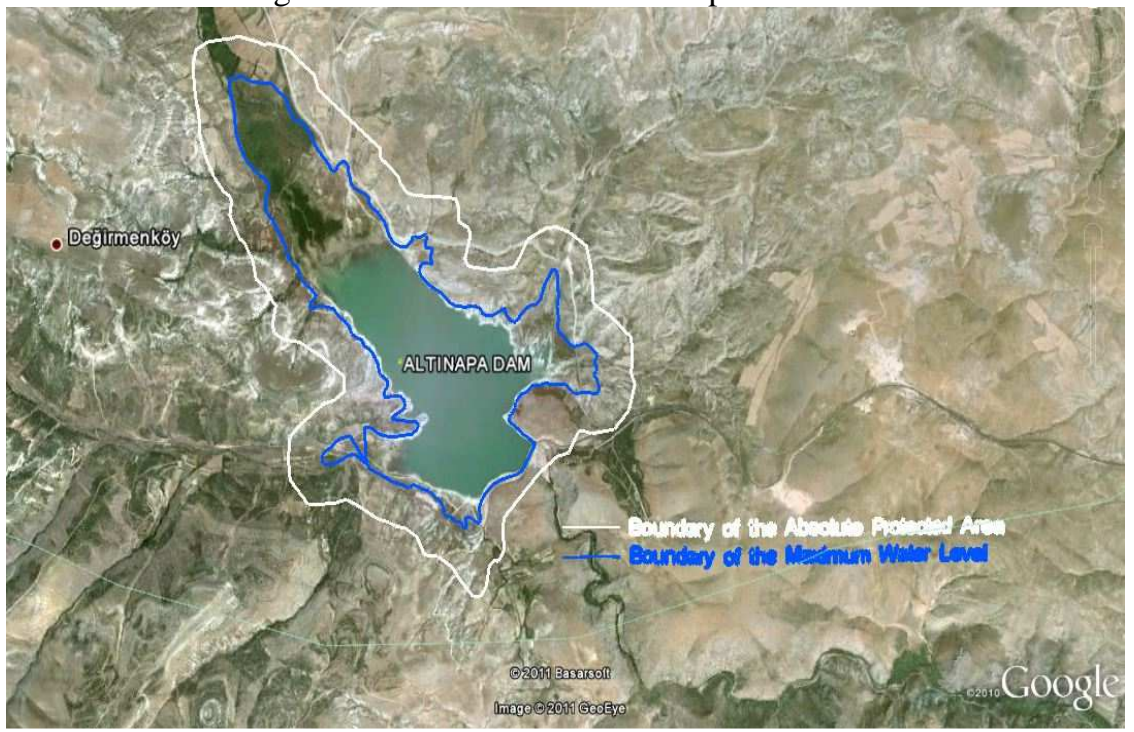

Bol. Ciênc. Geod., sec. Artigos, Curitiba, v. 20, no 1, p.142-158, jan-mar, 2014. 


\subsection{Geographical Information System}

A geographical information system (GIS) is an information system for the acquisition, preservation, analysis and presentation of graphical and non-graphical data based on locational operations. These characteristics geographical information systems mean they are used for data analysis in a wide range of applications. Data acquisition is the one of the most important phases, requiring the greatest time and cost, in realizing geographical information systems. During this stage, the efficient operation of the system requires regular data flow to the system. Data acquisition operations can be realized by various disciplines, depending on current technological developments (YOMRALIOĞLU, 2005).

\subsection{Topographical and Bathymetric Measurements}

Even if the application area of hydrographic measurements is limited to the coastline, to establish the connection between hydrographic maps and land, the coastline and some of its characteristics should be measured. Classical terrestrial techniques, Global Navigation Satellite System (GNSS), photogrammetric and remote-sensing methods are used for these measurements.

In this study, measurements were made using Topcon Precision GPS Hyperpro GPS receivers (RTK-GPS) and Topcon GPT 3007 electronic tachymeter. In bathymetric measurements, depth and location measurements should be conducted simultaneously to detect the location of the point in both horizontal and vertical planes. The updated method used in horizontal location measurements are Real Time Kinematic (RTK-GPS) or Differential GPS (DGPS). Acoustic methods are generally applied in depth measurements. Since the reservoir bottom is not directly visible, bathymetric measurements are conducted according to a previously determined direction, and at certain time intervals, and the resulting data is related to the water level at the time of measurement.

A double-frequency Matrix GPS 97 Humminbird Echo Sounder was used in depth measurements of Altınapa reservoir. Horizontal location information of the depth measurement points was acquired by an RTK-GPS with Topcon Precision GPS Hyperpro receiver. One of the GPS receivers was established on reference point while the other was mobile and used on the hydrographic boat. Bathymetric measurements were conducted on 2650 locations. Topographic and bathymetric measurement points are shown in Figure 2. The elevation of the water surface on the day of measurement was taken from the staff gage station of State Hydraulic Works (SHW) the 4 th. Regional Directorate. Reservoir bottom elevations were calculated by reducing the depths according to average water surface elevation. 
Figure 2- Locations of the topographic and bathymetric points

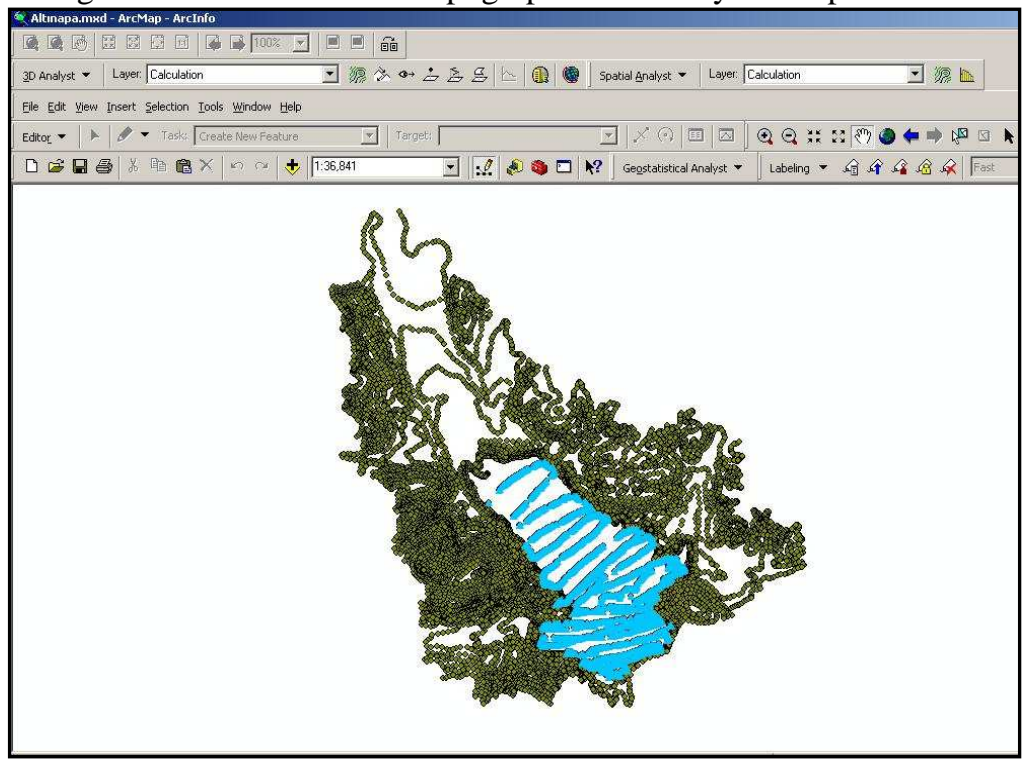

\subsection{Climatic Characteristics, Plant Cover and Geological Features}

A continental climate is predominant in Konya. The highest recorded temperature is in August and the lowest is in January. In general, it is hot and dry in summer and cold and wet in winter. Average annual precipitation and evaporation are $319.40 \mathrm{~mm}$ and $1317.5 \mathrm{~mm}$, respectively (Table 1).

Step and bosket vegetation is common around Altınapa Reservoir. The phytogeographical regions of local plants are Iran-Turan elements, Mediterranean elements, Europe-Siberia elements, wide ranged and unknown ranged (YIDIZTUGAY et al., 2006). There are also extensive forested areas within the study area. In Altınapa reservoir and its surrounding area, there exist agricultural land, oak stand and forest, other leaved stands in density age under $7.9 \mathrm{~cm}$, black pine and cedar stand in density age under $7.9 \mathrm{~cm}$, black pine stand in density age under $7.9 \mathrm{~cm}$, black pine productive stand in density age under $7.9 \mathrm{~cm}$, agricultural land and forest land, treeless forest land, swamp, sand, and productive plantation areas (KONYA REGIONAL DIRECTORATE of FORESTRY, 2011).

Geologically, the study area consists of Loras formation (TRjl), Dilekçi formation (Td), Küçükmuhsine formation (Tk), Erenkaya formation (Tde) and Sille formation (Tds). There are also alluvium (Qa) and talus (Qae) (Central Anatolian $2^{\text {th }}$ District Office of Mineral Research and Exploration, 2011). 
Table 1- Climatic features (Source: EKIZOGLU, 2011)

\begin{tabular}{|c|c|c|c|c|c|c|c|c|c|c|c|c|c|}
\hline \multicolumn{13}{|c|}{$\begin{array}{l}\text { Regional Directorate of Meterology (Konya) } \\
(1975-2008)\end{array}$} & \multirow[b]{2}{*}{$\begin{array}{l}\text { The total } \\
\text { average }\end{array}$} \\
\hline Months & Jan. & Febr. & Marc. & Apr. & May & June & July & Aug. & Sept. & Oct. & Nov. & Dec. & \\
\hline $\begin{array}{l}\text { Mean } \\
\text { temperature } \\
\left({ }^{\circ} \mathrm{C}\right)\end{array}$ & -0.3 & 0.9 & 5.4 & 10.9 & 15.6 & 20.1 & 23.4 & 22.9 & 18.5 & 12.4 & 5.6 & 1.3 & - \\
\hline $\begin{array}{l}\text { Average } \\
\text { evaporation of } \\
\text { surface }(\mathrm{mm})\end{array}$ & - & - & - & 96.6 & 162.8 & 218.9 & 277.5 & 258.1 & 182.9 & 106.3 & 14.3 & 0.1 & 1317.5 \\
\hline $\begin{array}{l}\text { Mean total } \\
\text { rainfall }(\mathrm{mm})\end{array}$ & 33.7 & 23.8 & 26.3 & 38.6 & 41.3 & 20.9 & 7.4 & 5.2 & 11.3 & 32.8 & 37.1 & 41 & 319.40 \\
\hline $\begin{array}{l}\text { Average } \\
\text { humidity }(\%)\end{array}$ & 76.4 & 70.8 & 62.9 & 58.3 & 55.8 & 47.6 & 42.2 & 42.9 & 47 & 59.5 & 70.1 & 76.8 & - \\
\hline
\end{tabular}

\subsection{Gathering Attribute Information}

Attribute information of Altınapa such as meteorological, plant cover, geological and forest features was gathered from the institutions shown in Table 2.

Table 2- Institutions and attribution data (Source: EKIZOGLU, 2011)

\begin{tabular}{|c|c|}
\hline Institutions & Received Information \\
\hline $\begin{array}{ll}\text { SHW } \quad 4^{\text {th }} & \text { Regional } \\
\text { Directorate } & \end{array}$ & $\begin{array}{l}\text { Bathymetric map from 1984, average water level } \\
\text { values, water supply values of Meram stream, } \\
\text { vaporization values of the dam, precipitation }\end{array}$ \\
\hline $\begin{array}{ll}\text { Konya } & \text { Special } \\
\text { Provincial } & \\
\text { Administration } & \\
\end{array}$ & $\begin{array}{l}1: 25.000 \text { scale map of Konya and transportation } \\
\text { roads of the dam }\end{array}$ \\
\hline $\begin{array}{l}\text { Konya Water and } \\
\text { Sewage Administration }\end{array}$ & Basin border map of the dam \\
\hline $\begin{array}{lcr}\text { Central Anatolian } & 2^{\text {nd }} \\
\text { District Office } & \text { of } \\
\text { Mineral Research and } \\
\text { Exploration }\end{array}$ & $\begin{array}{l}\text { Geological map of the region of the dam and } \\
\text { geological information }\end{array}$ \\
\hline $\begin{array}{l}\text { Konya Regional } \\
\text { Directorate of Forestry }\end{array}$ & s and information about plant cover \\
\hline $\begin{array}{lr}\text { Konya } & \text { Provincial } \\
\text { Department } & \text { of } \\
\text { Environment } & \text { and } \\
\text { Forestry } & \end{array}$ & bout trees in \\
\hline $\begin{array}{l}\text { Konya Directorate of } \\
\text { Meteorological Service }\end{array}$ & a province \\
\hline
\end{tabular}

\subsection{Water Quality Measurements}

Water quality measurements were conducted in conjunction with bathymetric measurements. Samples from 31 locations gave $\mathrm{pH}$, turbidity, dissolved oxygen and 
temperature values of water. A WTW 340i multi-parameter device and a $30 \mathrm{~cm}$ diameter Secchi disc were used in measurements.

\subsection{Digitalizing of Present Maps}

A geological map provided by the Regional Directorate of Mineral Research and Exploration (state agency), forest map provided by the Directorates of Forestry (state agency) and bathymetric maps from 1984 provided by the SHW 4th Regional Directorate were scanned at 300 dpi resolution and converted to TIFF (Tagged Image File Format) format and the map image registered by Affin Transformation with 4 common points between raster coordinates and map coordinates. After this process the map image transferred to vector format by manual digitizing.

\subsection{Integration of Data to GIS}

Location and attribute data of the study area was integrated into ArcGIS 9.2 software. To achieve this, first vectorial data (X, Y, H) acquired in Netcad was exported to ArcGIS 9.2 software in ESRI shape format (Figure 3). Then, a digital land model of the study area was obtained with the TIN (Triangulated Irregular Network) method using the 3D Analyst module (Figure 3). Digital land model data were converted to GRID data with TIN to raster module of 3D Analyst module. A forestry map of tree species, features and regions was produced with Add XY Data within the Tools module of ArcGIS 9.2 software (Figure 4); the geological map was similarly transferred to ArcGIS. The layers in the study area, their symbols and formation times were integrated into the program.

Physical and chemical features $(\mathrm{pH}$, dissolved oxygen, temperature and turbidity data) of lake water were transferred to ArcGIS as point data. Average water level of the reservoir, water supply data of Meram stream, evaporation values and precipitation data of the reservoir were added as GIS data layers. Plant species in the study area added to the GIS system as points. The elevation of the plants, their Latin names, local names, the elements they belong to and their locations were transferred to the GIS.

\section{RESULTS AND DISCUSSION}

Within the scope of this study, digital land models and bathymetric maps of Altınapa Reservoir for the years 1984 and 2009 were obtained using ArcGIS 9.2 software (Figure 5.a-5.b).

The surface areas and volumes of various water elevations of Altınapa Reservoir were examined using GRID data of digital elevation models of 1984 and 2009. According to the 1984 data, the surface area measured $3,256,000 \mathrm{~m}^{2}$ and reservoir volume was $28,940,000 \mathrm{~m}^{3}$ at the normal water level $(1253.40 \mathrm{~m})$. At the maximum water level $(1254.80 \mathrm{~m})$, surface area was calculated as $3,590,500 \mathrm{~m}^{2}$ and reservoir volume as $33,725,000 \mathrm{~m}^{3}$. According to the 2009 data, the surface area was $2796400.00 \mathrm{~m}^{2}$ and reservoir volume was $25,473,000 \mathrm{~m}^{3}$ at the normal water level $(1253.40 \mathrm{~m})$. At the maximum water level $(1254.80 \mathrm{~m})$, surface area was 
calculated as $2887410.00 \mathrm{~m}^{2}$ and reservoir volume as $29,444,400 \mathrm{~m}^{3}$. Surface areas and volumes at various water levels are shown in Figures 6 to 8 .

Figure 3- Digital elevation model map of 2009

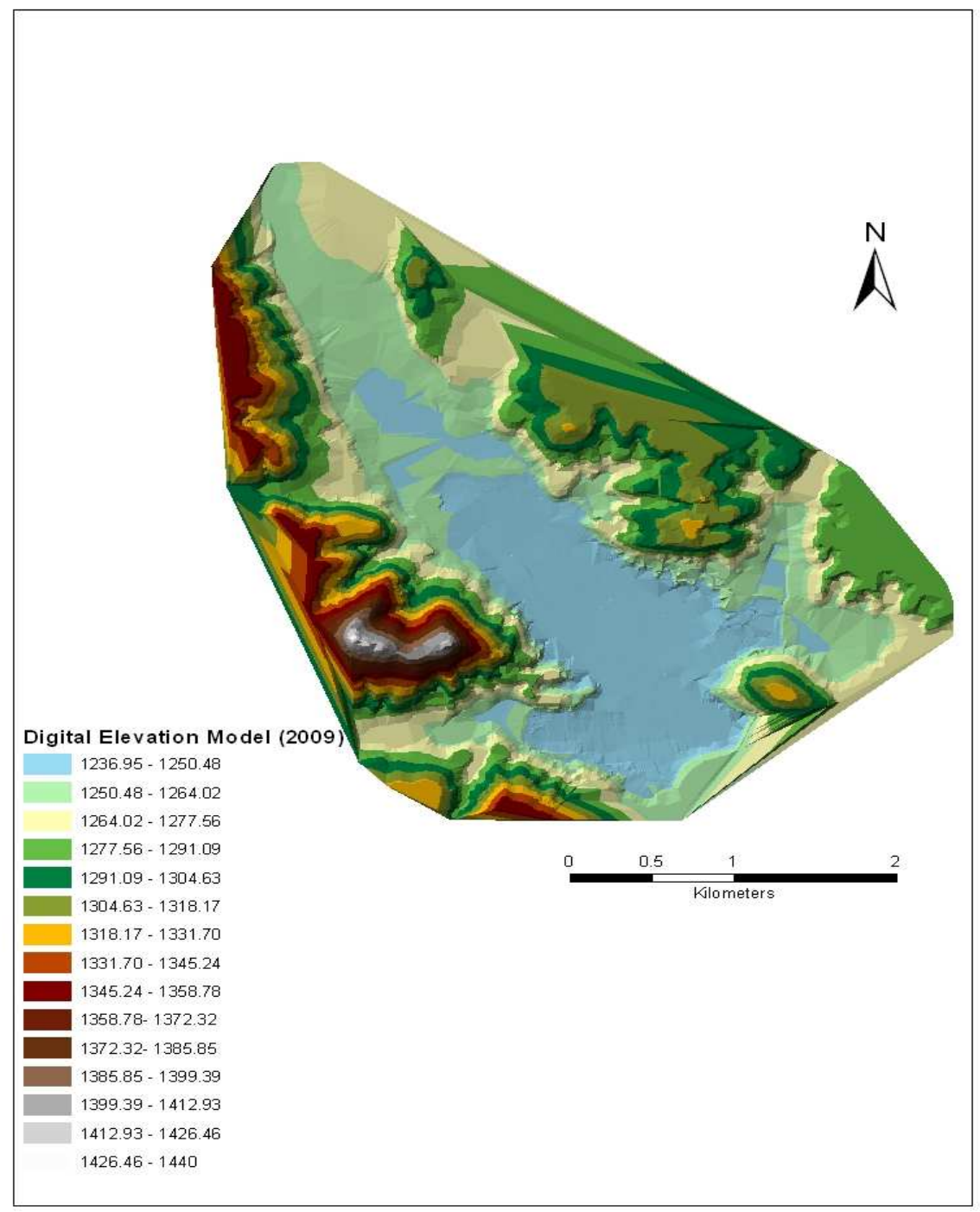

Bol. Ciênc. Geod., sec. Artigos, Curitiba, v. 20, no 1, p.142-158, jan-mar, 2014. 
Figure 4- Forest map

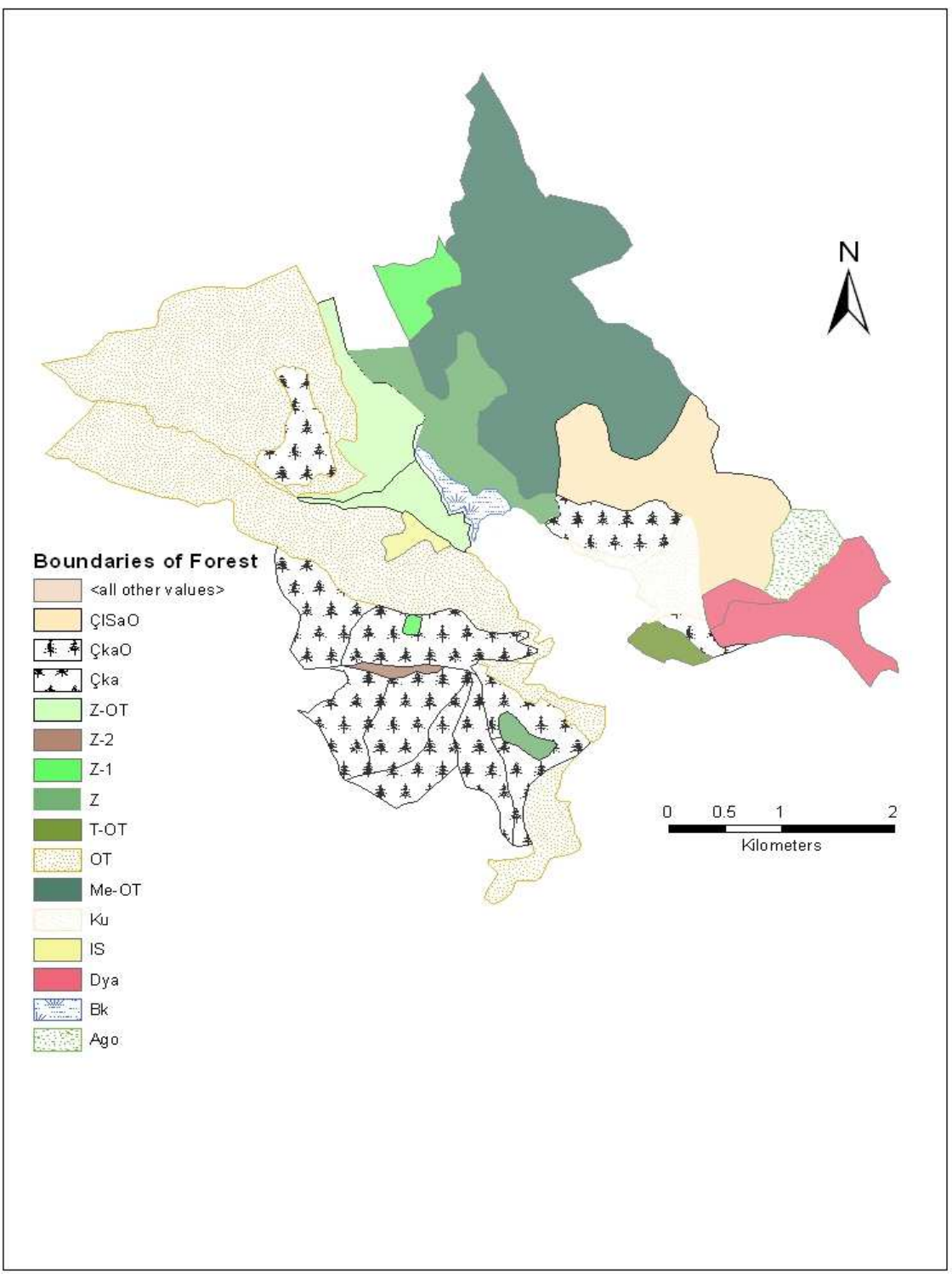

Bol. Ciênc. Geod., sec. Artigos, Curitiba, v. 20, nº 1, p.142-158, jan-mar, 2014. 
Figure 5.a- Map of bathymetric in 1984

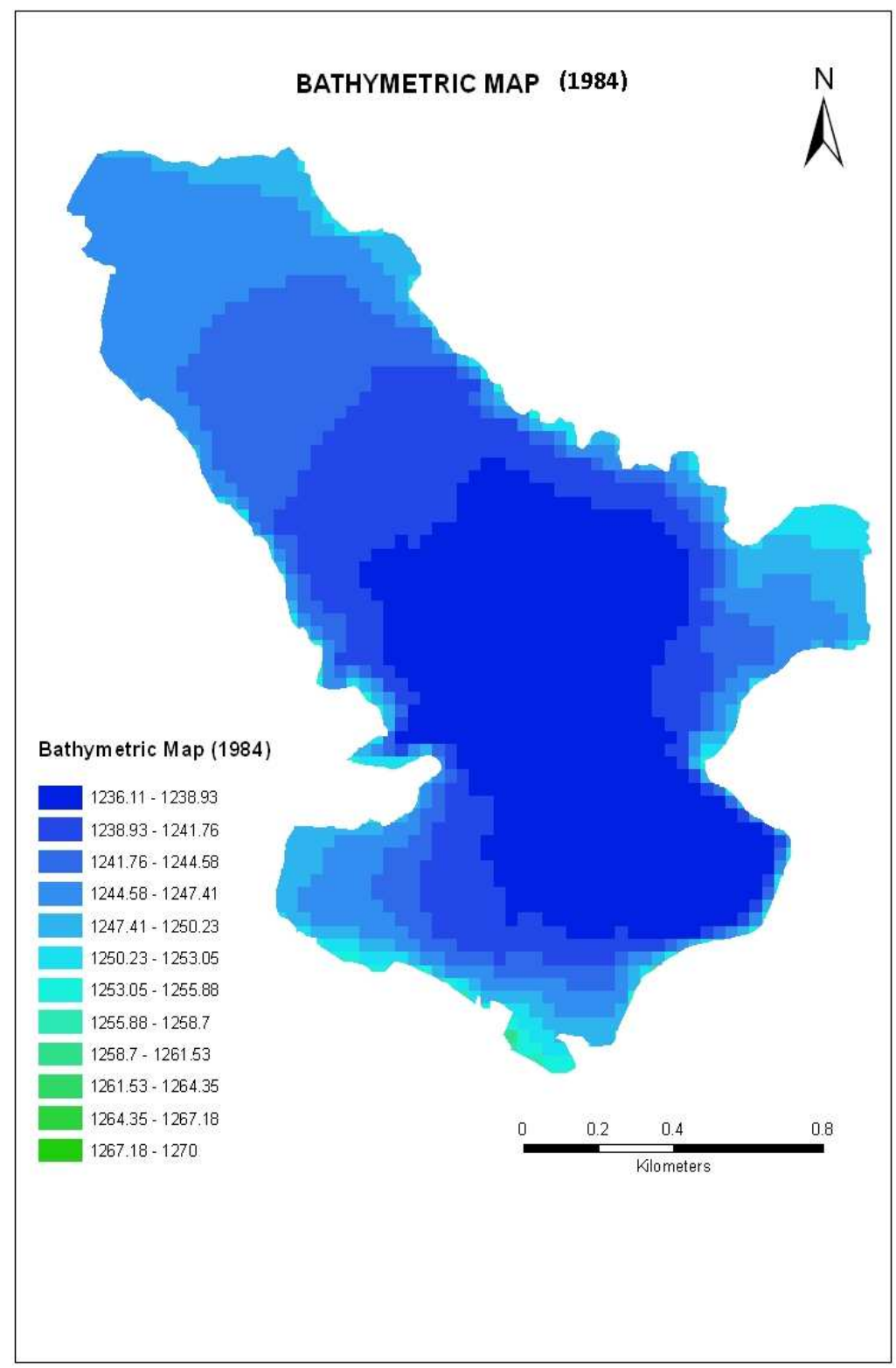

Bol. Ciênc. Geod., sec. Artigos, Curitiba, v. 20, no 1, p.142-158, jan-mar, 2014. 
Figure 5.b- Map of bathymetric in 2009

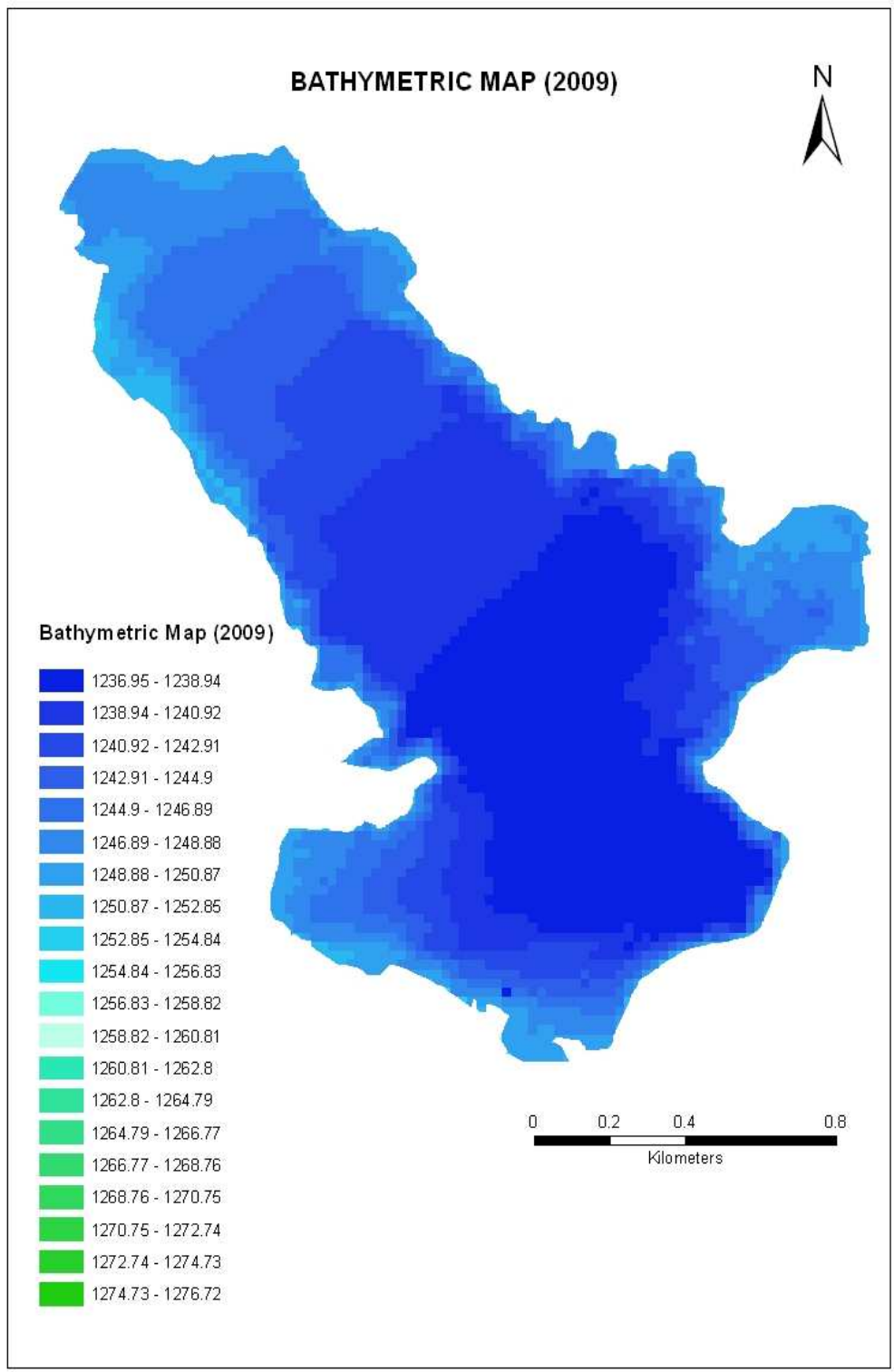

Bol. Ciênc. Geod., sec. Artigos, Curitiba, v. 20, nº 1, p.142-158, jan-mar, 2014. 
Figure 6- The surface areas at various water levels

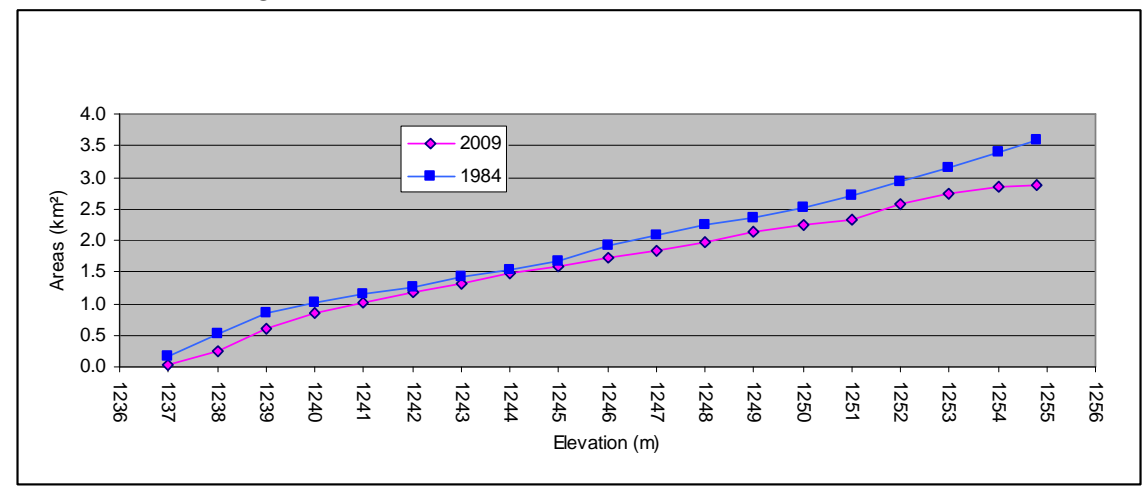

Figure 7- The volumes at various water level

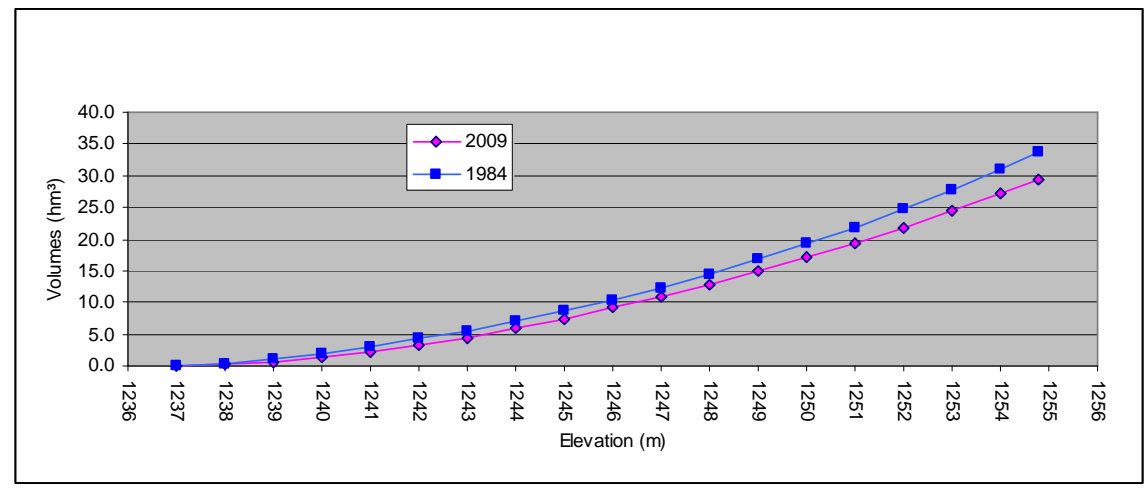

Figure 8- The area versus volume

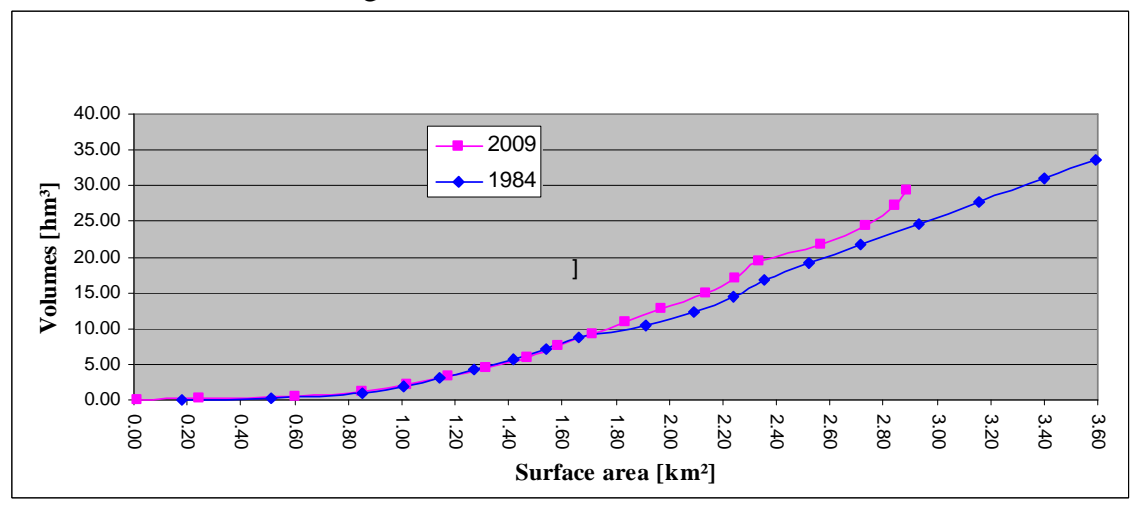

Bol. Ciênc. Geod., sec. Artigos, Curitiba, v. 20, nº 1, p.142-158, jan-mar, 2014. 
In this study, these results represent a reduction in volume of $12 \%$ according to normal water level and $12.7 \%$ according to maximum water level. The capacity of the reservoir (normal water level) was found to have decreased by an average of $171216 \mathrm{~m}^{3} /$ year (or $0.51 \%$ ). Previous studies on this issue reported that the capacity of the McConaughy Reservoir (USA) decreased by $0.03 \% / y e a r$, Overholser reservoir (USA) decreased by $0.29 \% / y e a r$, Seyhan reservoir (Turkey) decreased by $0.71 \% / y e a r$, and Sille reservoir (Turkey) decreased by $0.48 \% / y e a r$. Based on these values, it can be suggested that sedimentation is a serious threat to the continued operation of Turkey's reservoirs.

To determine changes in the reservoir bottom due to sedimentation, five distinct sections were taken from the reservoir (Figure 9). Maximum sediment thickness, average sediment thickness and standard deviation are shown in Table 3.

Table 3- Standard deviations and sediment thickness on the cross-sections

\begin{tabular}{c|c|c|c}
\hline Cross-sections & $\begin{array}{c}\text { Max. sediment } \\
\text { thickness (m) }\end{array}$ & $\begin{array}{c}\text { mean sediment } \\
\text { thickness (m) }\end{array}$ & $\begin{array}{c}\text { Standard } \\
\text { deviations (m) }\end{array}$ \\
\hline A-A' & 4.23 & 0.95 & \pm 1.15 \\
\hline B-B' & 0.97 & 0.65 & \pm 0.20 \\
\hline C-C' & 3.24 & 1.07 & \pm 0.63 \\
\hline D-D' & 1.61 & 0.69 & \pm 0.37 \\
\hline E-E' & 3.53 & 0.74 & \pm 0.77 \\
\hline
\end{tabular}

Plant species found at the reservoir and its surrounding area, geological data and forestry coverage and composition were presented to users in GIS (ArcGIS 9.2 software). Attribute values of the reservoir and its surrounding area were spatially referenced within the GIS and made available for examination. For example, users are able to investigate questions such as "Which tree species are present? What is the age groups of the trees? Where are the borders of tree species? What is the height of tree species? What is the location of tree species? What kinds of formations are observed? What are the formation years of these generations?" In addition, GIS data layers were produced, allowing the examination of reservoir water quality data (temperature, dissolved oxygen, Secchi disc, $\mathrm{pH}$ ).

The purpose of this study is to provide some information about the water quality of the basin, in some extent. For this, water quality parameters such as $\mathrm{pH}$, Secchi Disk Depth (SDD) and Dissolved Oxygen (DO) as well as Temperature, as in situ measurements.

$\mathrm{pH}$ : No health-based guideline value is proposed for $\mathrm{pH}$. Although, $\mathrm{pH}$ usually has no direct impact on consumers, it is one of the most important operational water quality parameters, with the optimum $\mathrm{pH}$ required often being in the range of 6.5-9.5. 
Figure 9- View of cross-section lines

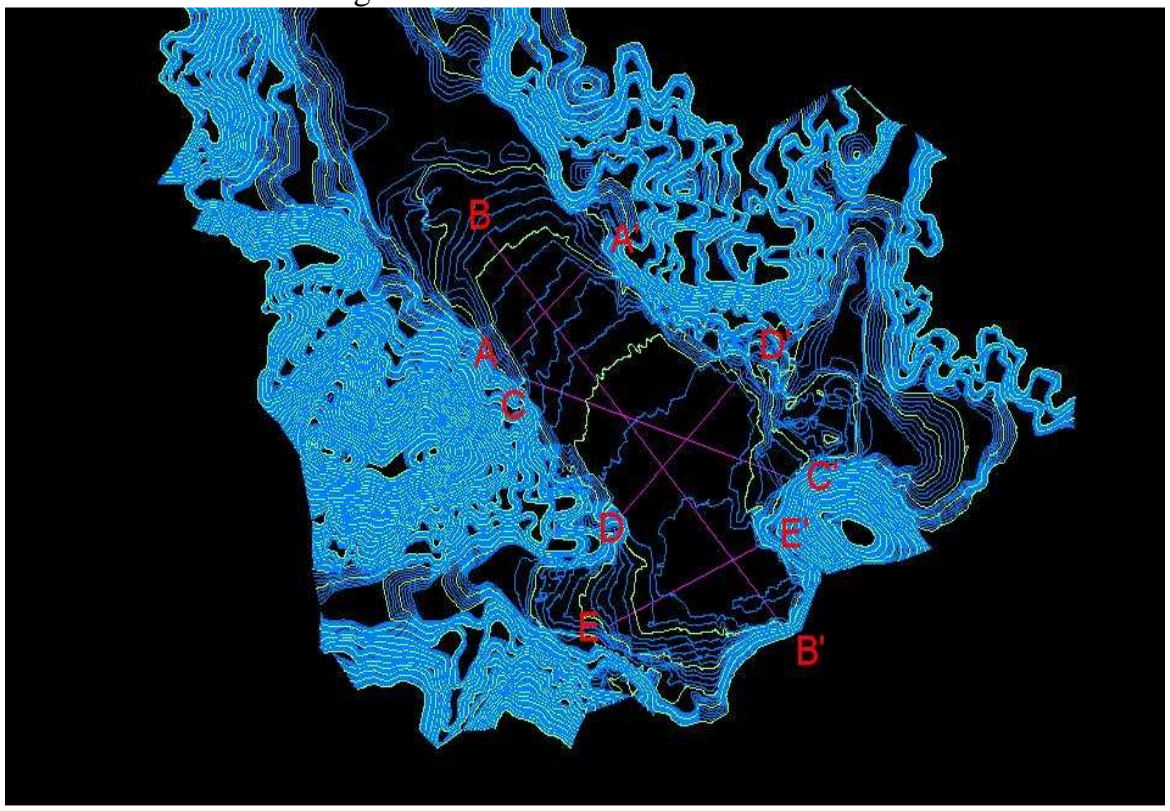

Secchi Disk Depth (SDD): An instrument used for measuring the clarity of water, especially lake water. This measure is known as the Secchi disk depth (SDD) and is related to water turbidity. SDD values were measured with a $20-\mathrm{cm}$ diameter HydroBios disk with alternating black and white quadrants. The disc is lowered into a section of shaded water until it can no longer be seen and is then lifted back up until it can be seen once again. Averaging the two depths gives the clarity of the water.

Dissolved Oxygen (DO): All living organisms are dependent upon oxygen in one form or another to maintain the metabolic processes. The solubility of atmospheric oxygen in fresh waters ranges from $14.6 \mathrm{mg} / \mathrm{L}$ at $0^{\circ} \mathrm{C}$ to about $7 \mathrm{mg} / \mathrm{L}$ at $35^{\circ} \mathrm{C}$ under $1 \mathrm{~atm}$ of pressure.

Temperature: The most common physical assessment of water quality is the measurement of temperature. Temperature impacts both the chemical and biological characteristics of surface water. It affects the dissolved oxygen level in the water, photosynthesis of aquatic plants, metabolic rates of aquatic organisms, and the sensitivity of these organisms to pollution. Warm water is less capable of holding dissolved oxygen. For this reason, temperature should be measured at the same place within the stream at which dissolved oxygen is measured. This allows the correlation between the two parameters to be observed. The problem of low dissolved oxygen levels is magnified by the fact that the metabolic rates of aquatic plants 
increase as water temperature rises, thus increasing their biochemical oxygen demand. Low dissolved oxygen levels leave aquatic organisms in a weakened physical state and more susceptible to disease, parasites, and other pollutants.

The $\mathrm{pH}$ range of between 8.08-8.89 was measured in water taken from sampling point in basin. The Secchi Disk Depth (SDD) values of $50-125 \mathrm{~cm}$ obtained from the basin water samples. Dissolved Oxygen (DO) level of the basin is however ranged from 7.11 to $9.80 \mathrm{mg} / \mathrm{L}$ all over the basin. Temperature variation of the basin water is from 11.1 to $11.7{ }^{\circ} \mathrm{C}$ in basin during the sampling period of this investigation.

\section{CONCLUSIONS}

For effective management of water resources, first, water should be stored in environments such as dams or ponds, wherever possible. In addition, prevention of water pollution, up-to-date topographic and bathymetric information on reservoirs, changes in reservoir storage capacities due to erosion and sedimentation are given priority. In this context, this study was carried out to determine topographic and bathymetric situation, and the changes in the surface areas and volume due to sedimentation and erosion, in Altınapa reservoir. The study also aimed to present the Reservoir Information System (RIS) for use by relevant institutions, involving data on the geological structure, plant cover, physical and chemical features of the water of Altınapa reservoir.

Computations were made on ArcGIS software using digital elevation models of the lake based on date from the years 1984 and 2009. The data indicated that, over the 25 -year period between the two datasets, the storage capacity of the lake decreased to $4,280,400 \mathrm{~m}^{3}$, a reduction of $12.7 \%$. The capacity of the lake therefore decreased by $171,200 \mathrm{~m}^{3} /$ year (or $0.51 \%$ ) on average. This value is consistent with the results of previous studies and is much greater than global and European averages.

Five cross-sections of the reservoir were taken to analyze bathymetric changes in the reservoir base. The data indicated that, in coastal sections of the reservoir, the depth was reduced by between 0.97 and $4.23 \mathrm{~m}$, inner sections of the reservoir, where the reservoir base is lower; there were changes of between 0.15 and $0.95 \mathrm{~m}$. The mean sediment thickness was obtained to be $0.82 \mathrm{~m}$.

In this study we tried to construct a Reservoir Information System by collecting data on water elevation changes in Altınapa reservoir, physical and chemical properties of reservoir water, topographic and bathymetric data of the reservoir and its surrounding, plant species, geology and forest maps etc. within a single database, using ArcGIS 9.2 software. The system aimed to allow users to conduct spatial inquiries and analyses.

The General Directorate of State Hydraulic Works, which is the only authority regulating all functions related to dams in Turkey, has important roles in operating and conserving the reservoirs. In this respect, State Hydraulic Works should 
perform the following activities to create a Reservoir Information System, similar to those in European countries and the USA.

Topographic and bathymetric measurements of each reservoir and its surrounding should be renewed at five year intervals. The storage capacity of a reservoir can be determined by evaluating these measurements.

Deformations occurring in the dam embankment due to underground tectonic movements should be monitored. These deformations should be analyzed to determine whether they threaten dam safety.

Measurements should be made to determine the amount of sweeping material carried by the rivers and creeks that supply water to the reservoirs. The degree and amount of the threat to the reservoir caused by sedimentation should be determined and reservoir improvement activities should be conducted.

Environmental monitoring applications, which cover reservoir area, have importance in the way of environmental and sustainability issues. Using GIS in such studies has many advantages to managers for both analyze and decision making process.

\section{ACKNOWLEDGEMENTS}

The author thanks Selçuk University Department of Underwater Archeology, who supplied the hydrography boat and acoustic bathometer device used in the study; Prof. Dr. Ali Berktay and Res. Asst. Ahmet Aygün, members of Selçuk University Department of Environmental Engineering, Ahmet Özdendinler, Kadir Caran, Ferhat Çayıroğlu, Alper Nartar and Ahmet Toprakkale, who contributed to this study.

\section{REFERENCES}

BODDY, N.N. \& GANSKE, L. Bathymetric Changes within Lake Zumbro of Olmsted County. Hydrologic Study of Produced by the Minnesota Pollution Control Agency, p. 1-21, 2005.

CEYLAN, A., KIRTILOĞLU, O. S., SARI, F., EKIZOĞLU, İ. An Analysis of Bathymetric Changes in Sille Dam Reservoir Between 1984 and 2008. 10. International Multidisciplinary Scientific GeoConference SGEM 2010, Bulgaria, p.387-394, 2010.

CEYLAN, A., KARABÖRK, H., EKIZOĞLU, İ. An Analysis of Bathymetric Changes in Altinapa Reservoir. Carpathian Journal of Earth and Environmental Sciences, 6(2), p.15-24, Romania, 2011.

CHILDS, J. R., SNYDER, N. P. AND HAMPTON, M. H. Bathymetric and geophysical surveys of Englebright Lake. Yuba-Nevada Counties, California, US Geological Survey Open-File Report 03-383, p.20, 2003 http://geopubs.wr.usgs.gov/open-file/of03-383/ (Accessed on 29 March 2010)

CREECH, J., DASLER, J., PEERY, G. Fusing GIS and Hydrography for Search and Recovery Operations: Two Case Studies. U. S. Hydro 2005, San Diego, California, USA, 2005. 
DAVID C. JORDAN and MARK A. FONSTAD, Two Dimensional Mapping of River Bathymetry and Power using Aerial Photography and GIS on the Brazos River, Texas, Geocarto International, Vol. 20, No. 3, 1-8, 2005.

EL-SERSAWY, H.05). Sediment Deposition Mapping In Aswan High Dam Reservoir Using Geographic Information System (GIS). Ninth International Water Technology Conference, Iwtc9 2005, p.239-247, Sharm El-Sheikh, Egypt, 2005.

EKIZOGLU, I. A Study on The Assessment of Bathymetric Mapping with Geographic Information System: Altınapa Dam (Konya) Example. Master Thesis, 87, The Graduate School of Natural And Applied Science of Selcuk University, Konya, Turkey, 2011, (in Turkish).

GÜVEL, Ş. P. The Study On Sediment Accumulation of Seyhan Reservoirs By Decision Support Systems. Ph. D Thesis, 212, Department of Civil Engineering Institute of Natural and Applied Sciences University of Çukurova, Adana, Turkey, 2007. (in Turkish).

KRESS ,W. H., SEBREE, S. K., LITTIN, G. R., DRAIN, M. A., KLING, M. E. Comparison of Preconstruction and 2003 Bathymetric and Topographic Surveys of Lake McConaughy. Scientific Investigations Report, 2005-5040. Published by U.S. Department of the Interior and U.S. Geological Survey, May, 2005.

MILLETT, G. N., EVANS, S. Hydrographic Data Management Using GIS Technologies. Environmental Systems Research Institute, New York, USA, 2009.

YOMRALIOĞLU, T. Geographic Information Systems: Basic Concepts and Applications. IBER Ofset Publisher, Trabzon, p.32-148, 2005.

http://digitalcommons.unl.edu/cgi/viewcontent.cgi?article=1004\&context=usgspubs , (Accessed on 03 August 2009)

YILDIZTUGAY, E., BAĞCI, Y., TUGAY, O. The Flora of Region Among

Başarakavak, Tatköy and Altınapa Dam (Konya)., Master thesis, Selçuk University, p.162, Konya, Turkey, 2006.

Central Anatolian 2 th. District Office of Mineral Research and Exploration, Technical report, 2011.

Konya Regional Directorate of Forestry, Technical report, 2011

(Recebido em julho de 2013. Aceito em novembro de 2013). 